\title{
IgM Antibodies to Schistosoma mansoniGut-associated Antigens for the Study of Schistosomiasis Transmission in Ribeirão Pires, São Paulo
}

\author{
Vera LF Camargo-Neves, Herminia Y Kanamura*/+, Sylvia AG Vellosa**, \\ Cybele Gargioni**, Luiz Candido S Dias***
}

\begin{abstract}
Superintendência de Controle de Endemias, SES, Rua Paula Souza 166, 01027-000 São Paulo, SP, Brasil *Faculdade de Ciências Farmacêuticas, Universidade de São Paulo, São Paulo, SP, Brasil **Instituto Adolfo Lutz, SES, São Paulo, SP, Brasil ***Faculdade de Ciências Médicas, Universidade Estadual de Campinas,

Campinas, SP, Brasil
\end{abstract}

The potential of an immunofluorescence test for detection of IgM antibodies against Schistosoma mansoni gut-associated antigens (IgM-IFT) was evaluated as a tool for studying aspects related to the schistosomiasis transmission in Ribeirão Pires, in the metropolitan area of the capital of the State of São Paulo, Brazil. Children from a school with about 400 students, 6 to 18 years, were followed-up for two years. In the five surveys, carried out at 6-month intervals, from October 92 to October 94, serological (IgM-IFT) prevalence indices of 5.3\%, 5.8\%, 6.2\%, 2.9\% and 3.3\% were obtained. These indices were 7 to 10 times higher than the parasitological prevalence indices of $0.5 \%, 0.5 \%, 0.7 \%, 0.4 \%$ and $0 \%$ determined by the Kato-Katz method. Seroconversion from IFT negative to positive was indicating possible newly acquired $\mathrm{S}$. mansoni infection in three children. But confirmation of infection by fecal examination was possible in only one child. The IgM-IFT can constitute a valuable tool for the improvement of the vigilance program in low endemic areas for schistosomiasis, better characterizing the $\mathrm{S}$. mansoni transmission in such areas.

Key words: Schistosoma mansoni - epidemiology - immunodiagnosis - seroconversion

Schistosomiasis in Brazil today can be considered as a mild disease, with reduced morbidity, in almost all the areas used to be endemic for this disease in the different states. This is also true in the State of São Paulo, where the reduced morbidity is due mainly to the low worm burden of the infected individuals; so, the schistosomiasis endemic areas in the state have been characterized as low endemic areas. Nevertheless, schistosomiasis persists to be a serious problem of public health, requiring attention of health authorities. If no control measures are taken, there is a real risk of expansion of the schistosomiasis to before safe areas, and also of return to the high levels of prevalence and serious morbidity observed in the past, in some areas.

In the Metropolitan Region of São Paulo, the available data in Sucen (Superintendence of the Control of the Endemic Diseases of the State of São Paulo Government) can point out that the au-

\footnotetext{
${ }^{+}$Corresponding author. Fax: $+55-11-813.2197$. E-mail: kanamura@usp.br Received 4 May 1998 Accepted 31 August 1998
}

tochthonous transmission of schistosomiasis occurred in 26 municipalities, in the last 10 years (1988 to 1997). During this period, in this area, composed by the Capital of the state and 38 surrounding municipalities, 276 autochthonous cases were registered. The autochthonous cases constituted only $0.3 \%$ of the total of 87,176 schistosomiasis cases imported from other states or other endemic regions of the State of São Paulo. This small number of autochthonous cases registered each year indicates that schistosomiasis transmission in Great São Paulo is low and happens sporadically. The majority of the infected individuals in Great São Paulo present low worm burden and eliminate less than $50 \mathrm{egg} / \mathrm{g}$ feces. The snail host was identified as Biomphalaria tenagophila. The analysis of the data of the epidemiological investigation records of the coprological surveys, and of the snail searches, showed that the transmission of schistosomiasis in Great São Paulo was not always associated to the presence of infected snails in the foci. Many autochthonous cases were associated to different water courses, where the presence of infected snails was not possible to be demonstrated in repeated searches (Sucen 1989a, b).

In Ribeirão Pires, one of the municipalities in the Great São Paulo, 65 autochthonous cases of 
schistosomiasis were reported between 1981 and 1989, giving an autochthonous prevalence data of 9.2 cases per 100,000 inhabitants. Between 1990 and 1997, only 13 cases were notified, reducing the autochthonous prevalence data to 1.4 cases per 100,000 inhabitants. But sporadically new schistosomiasis autochthonous cases have been notified in the different areas of the state, indicating the need of a continuous vigilance program. Because of the low worm burden, the majority of the infected individuals show no clinical symptoms, and even when present, they are vague and not specific. This constitutes a limitation for the clinical diagnosis of the disease. The fecal parasitological examination, as routinely used in the Public Health Laboratories, have shown to be inefficient for the detection of individuals excreting less than 100 eggs per gram of feces (Barreto et al. 1990, De Vlas \& Gryseels 1992, Engels et al. 1996). These observations suggest that more sensitive diagnostic techniques need to be incorporated into the schistosomiasis control programs.

In the present paper, an immunodiagnostic technique, the immunofluorescence test for detection of IgM antibodies against Schistosoma mansoni gut antigens of polysaccharide nature (Nash 1978), was evaluated for epidemiological purposes. A group of schoolchildren living in the municipality of Ribeirão Pires, in Great São Paulo, was followed for a period of two years. Five surveys were carried out, in order to verify the potentiality of the IgM-IFT as a tool for epidemiological studies and for understanding the dynamics of schistosomiasis transmission in the area of Great São Paulo.

\section{MATERIALS AND METHODS}

Description of study area and population - A group of children from a school located in Jardim Mirante, in a peri-urban area of the municipality of Ribeirão Pires, was followed in this study. Ribeirão Pires, with a total area of $40 \mathrm{~km}^{2}$ and population of 85,034 inhabitants, in 1991 (Emplasa 1994), is one of the 39 municipalities of the Great São Paulo. In the last 10 years (1988 to 1997), 206 cases of schistosomiasis were notified, 21 of them being autochthonous and the others imported from other Brazilian states, mainly Bahia, Minas Gerais and Pernambuco. From the 21 autochthonous cases, seven $(33.3 \%)$ were detected through the coprological surveys carried out by Sucen and the others were notified by the Public Health System. In the locality of Jardim Mirante, the recreational activities like swimming and playing in the water seem to be the main reasons for schistosomiasis transmission. Fecal samples and capillary blood from a fingertip were collected from the children registered in the Escola Estadual de Primeiro e Segundo
Grau "Anna Lacivita Amaral", in five surveys. The 1 st, 3rd and 5th surveys were carried out respectively in 1992, 1993 and 1994, in the second semester of each year, after the winter holidays. The 2 nd and 4th surveys were carried out after the summer holidays, during the first semester of 1993 and 1994, respectively. Only individuals found to be excreting $S$. mansoni eggs were treated with oxamniquine (20-25 $\mathrm{mg} / \mathrm{kg}$ body weight).

Immunofluorescence test (IFT) - IgM antibodies to S. mansoni gut antigens on Rossman's solution fixed adult worm paraffin sections were detected by IFT, according to the technique previously described (Silva et al. 1992). Several drops of capillary blood from a fingertip were collected from each individual onto a Whatman \#3 filter paper, dried at room temperature and stored in a plastic bag at $-20^{\circ} \mathrm{C}$. For the IFT, the dried blood spot discs were cut from the filter by a punch with $8 \mathrm{~mm}$ diameter. The paper discs were eluted in $120 \mathrm{ml}$ of $0.01 \mathrm{M} \mathrm{pH} 7.2$ PBS (Phosphate buffer solution), incubating overnight at $4^{\circ} \mathrm{C}$. The serum dilution after elution and removal of the paper disc was estimated to be 1:16 (Ferreira \& Carvalho 1982). A commercial anti-human IgM fluorescent conjugate (Biolab, Rio de Janeiro, Brazil) was used according to the respective titers determined by block titration against known positive and negative standard serum samples. It was given as positive result only the reaction showing fluorescence on gut associated antigen, as described (Kanamura et al. 1991).

Fecal examination - In each survey, the KatoKatz technique (Katz et al. 1972) was performed in only one fecal specimen from each schoolchild. In the serologically positive children, parasitological method was repeated in two more fecal samples.

Statistical analyses - Data from the five surveys were entered into a microcomputer using the Epi Info version 6.02 database package (Dean et al. 1995) and the same program was used to analyze the results from each survey.

\section{RESULTS}

The data presented in Table I show, in the five surveys, a significantly higher prevalence of schistosomiasis by the serological (IgM-IFT) method in comparison to the parasitological (Kato-Katz) method. In the last two surveys, a great number of children did not submit fecal samples to the diagnostic test, with some prejudice in the analysis of the data.

The prevalence data for other helminth species detected by Kato-Katz in the 1st survey were: 16.5\% for Ascaris lumbicoides, $17.7 \%$ for Trichuris trichiura, $0.5 \%$ for Enterobius vermicularis, $0.2 \%$ for hookworm, and $0.2 \%$ for Taenia sp. 
Table II presents the parasitological and serological prevalence rates according to the age group, only in the first survey. The two positive cases detected by the parasitological (Kato-Katz) method were from the oldest age group, one of 15 and the second of 17 years old, both males. Tendency to higher positivity rates in the older age groups can be observed by the serological method (IgM-IFT).
Of 162 schoolchildren who submitted five blood samples for serologic test, one in each survey, $151(93.2 \%)$ remained IgM-IFT negative throughout the follow-up study, and only $6(3.7 \%)$ presented positive IFT results in all five surveys (Table III). Occurrence of seroconversion, changing from IgM-IFT-negative in the 1st survey to positive in the 2 nd survey, indicating possible new acquisition of $S$. mansoni infection, was observed

\section{TABLE I}

Comparative results of the prevalence indices by parasitological (Kato-Katz) and serological (IgM-IFT) methods obtained for the five surveys carried out on the schoolchildren from a school of Jardim Mirante, in the municipality of Ribeirão Pires

\begin{tabular}{|c|c|c|c|c|c|c|c|}
\hline \multirow{3}{*}{ Survey } & \multicolumn{4}{|c|}{ Kato-Katz } & \multicolumn{3}{|c|}{ IgM-IFT } \\
\hline & \multirow{2}{*}{$\begin{array}{l}\text { Total No. } \\
\text { (F/M) }\end{array}$} & \multirow{2}{*}{$\begin{array}{l}\text { Total }^{a} \\
(\mathrm{~F} / \mathrm{M})\end{array}$} & \multicolumn{2}{|c|}{ Positives } & \multirow{2}{*}{$\begin{array}{l}\text { Total }^{b} \\
(\mathrm{~F} / \mathrm{M})\end{array}$} & \multicolumn{2}{|c|}{ Positives } \\
\hline & & & No. (F/M) & $\%$ & & No. (F/M) & $\%$ \\
\hline 2nd sem/92 & $\begin{array}{c}402 \\
(195 / 207)\end{array}$ & $\begin{array}{c}400 \\
(193 / 207)\end{array}$ & $\begin{array}{c}2 \\
(0 / 2)\end{array}$ & $\begin{array}{c}0.5 \\
(0.1-2.0)^{c}\end{array}$ & $\begin{array}{c}377 \\
(182 / 195)\end{array}$ & $\begin{array}{c}20 \\
(6 / 14)\end{array}$ & $\begin{array}{c}5.3 \\
(3.3-8.2)^{c}\end{array}$ \\
\hline 1 st $\mathrm{sem} / 93$ & $\begin{array}{c}404 \\
(190 / 214)\end{array}$ & $\begin{array}{c}367 \\
(175 / 192)\end{array}$ & $\begin{array}{c}2 \\
(0 / 2)\end{array}$ & $\begin{array}{c}0.5 \\
(0.1-2.2)\end{array}$ & $\begin{array}{c}382 \\
(181 / 201)\end{array}$ & $\begin{array}{c}22 \\
(7 / 15)\end{array}$ & $\begin{array}{c}5.8 \\
(3.7-8.7)\end{array}$ \\
\hline 2nd sem/93 & $\begin{array}{c}363 \\
(175-188)\end{array}$ & $\begin{array}{c}292 \\
(143-149)\end{array}$ & $\begin{array}{c}2 \\
(0 / 2)\end{array}$ & $\begin{array}{c}0.7 \\
(0.1-2.7)\end{array}$ & $\begin{array}{c}321 \\
(160 / 161)\end{array}$ & $\begin{array}{c}20 \\
(6 / 14)\end{array}$ & $\begin{array}{c}6.2 \\
(3.9-9.6)\end{array}$ \\
\hline 1 st sem/94 & $\begin{array}{c}399 \\
(192-207)\end{array}$ & $\begin{array}{c}258 \\
(130-128)\end{array}$ & $\begin{array}{c}1 \\
(0 / 1)\end{array}$ & $\begin{array}{c}0.4 \\
(0.02-2.5)\end{array}$ & $\begin{array}{c}383 \\
(183 / 200)\end{array}$ & $\begin{array}{c}11 \\
(3 / 8)\end{array}$ & $\begin{array}{c}2.9 \\
(1.5-5.2)\end{array}$ \\
\hline 2nd sem/94 & $\begin{array}{c}390 \\
(184 / 206)\end{array}$ & $\begin{array}{c}287 \\
(147 / 140)\end{array}$ & 0 & $\begin{array}{c}0 \\
(0-1.6)\end{array}$ & $\begin{array}{c}368 \\
(171 / 197)\end{array}$ & $\begin{array}{c}12 \\
(2 / 10)\end{array}$ & $\begin{array}{c}3.3 \\
(1.8-5.8) \\
\end{array}$ \\
\hline
\end{tabular}

Total No.: number of children enrolled in the project, in each survey; $a$ : total number of fecal samples submitted to Kato-Katz, in each survey; $b$ : total number of blood samples submitted to IgM-IFT, in each survey; F: female; M: male; $c$ : (95\% confidence intervals).

\section{TABLE II}

Prevalence indices for schistosomiasis by parasitological (Kato-Katz) and serological (IgM-IFT) methods, according to age group (data from the first survey)

\begin{tabular}{|c|c|c|c|c|c|c|}
\hline \multirow{3}{*}{$\begin{array}{c}\text { Age group } \\
\text { (years) }\end{array}$} & \multicolumn{3}{|c|}{ Kato-Katz } & \multicolumn{3}{|c|}{ IgM-IFT } \\
\hline & \multirow[t]{2}{*}{ Total $^{a}$} & \multicolumn{2}{|c|}{ Positives } & \multirow[t]{2}{*}{ Total $^{b}$} & \multicolumn{2}{|c|}{ Positives } \\
\hline & & No. & $\%$ & & No. & $\%$ \\
\hline $7-8$ & 72 & 0 & $\begin{array}{c}0 \\
(0-6.3)^{c}\end{array}$ & 69 & 1 & $\begin{array}{c}1.4 \% \\
(0.1-8.9)^{c}\end{array}$ \\
\hline $9-10$ & 104 & 0 & $\begin{array}{c}0 \\
(0-4.4)\end{array}$ & 96 & 2 & $\begin{array}{c}2.1 \% \\
(0.4-8.0)\end{array}$ \\
\hline $11-12$ & 97 & 0 & $\begin{array}{c}0 \\
(0-4.7)\end{array}$ & 93 & 5 & $\begin{array}{c}5.4 \% \\
(2.0-12.7)\end{array}$ \\
\hline $13-14$ & 87 & 0 & $\begin{array}{c}0 \\
(0-5.3)\end{array}$ & 81 & 5 & $\begin{array}{c}6.2 \% \\
(2.3-14.4)\end{array}$ \\
\hline $15-18$ & 40 & 2 & $\begin{array}{c}5.0 \% \\
(0-18.2)\end{array}$ & 38 & 7 & $\begin{array}{c}18.4 \% \\
(8.3-34.9)\end{array}$ \\
\hline Total & 400 & 2 & $\begin{array}{c}0.5 \% \\
(0.1-2.0)\end{array}$ & 377 & 20 & $\begin{array}{c}5.3 \% \\
(3.3-8.2)\end{array}$ \\
\hline
\end{tabular}

$a$ : total number of fecal samples submitted to Kato-Katz, in each category; $b$ : total number of blood samples submitted to IgM-IFT, in each category; $c$ : (95\% confidence intervals). 
in three children (Table III). The confirmation of the $S$. mansoni infection through the parasitological method was possible in one case, but there is a possibility that this child can have acquired the infection in other state.

The analysis of the IgM-IFT results, among the children who submitted at least four blood samples to the serological test, showed 114 cases with negative results throughout the study and only five with positive results in the four samples. This observation confirmed the data obtained in those children who submitted five blood samples.

Only five cases showed occurrence of seroconversion in two subsequent surveys, independently of the results in the previous or posterior surveys. In four cases, the seroconversion was observed form the 1st to the 2nd survey (the three cases showed in Table III are included here), and in one, from the 2 nd to the 3 rd survey.

\section{DISCUSSION}

In the present study, a serological technique, the immunofluorescence test (IFT) on S. mansoni worm paraffin sections, for detection of IgM antibodies to gut-associated antigens (Nash 1978), was studied. It was evaluated as a tool for understanding the dynamics of schistosomiasis transmission in one of the municipalities of the Metropolitan Region of São Paulo (Great São Paulo). Thus, a group of children from a school located in Jardim Mirante, in the peri-urban area of the municipality of Ribeirão Pires, was followed for a period of two years, with five surveys, one in each semester. The serological data were compared to the results obtained by the parasitological method.

The good sensitivity of the IgM-IFT for the diagnosis of both, acute and chronic schistosomiasis, was already demonstrated in previous papers (Kanamura et al. 1991, Silva et al. 1992). The presence of cross reactive IgG antibodies, in serum samples of patients with helminth infections other than Schistosoma, was detected by different au- thors when tested with total antigens of $S$. mansoni by ELISA and Western blot (Correa-Oliveira et al. 1988, Valli et al. 1997). Nevertheless, good specificity $(98.2 \%)$ was observed when detection of IgM antibodies to gut-associated antigens by IFT was applied in a different area of São Paulo with no schistosomiasis and high prevalence for other helminth infections, such as ascaridiasis, trichuriasis, and enterobiasis (Kanamura et al. 1998a). These previous data permitted us to interpret the IgMIFT positive data obtained in this study as possibly due to an actual or a previous contact with $S$. mansoni cercariae, even though $25 \%$ of children were detected as infected for other helminth species, in the studied school population.

In all five surveys, the positivity indices obtained by the serological IgM-IFT method were significantly higher than the indices by the parasitological Kato-Katz method (Table I). This observation is not different from results presented in other epidemiological studies, carried out in Brazil or outside, using different serological and parasitological methods (Dias et al. 1971, 1992, Kawazoe et al. 1981, Hoshino-Shimizu et al. 1986, Eltiro et al. 1992, Idris et al. 1994, Noya et al. 1995). However, the serological positivity rates, varying from 2.9 to $6.2 \%$ (Table I), obtained for the schoolchildren of Jardim Mirante, Ribeirão Pires, were lower than the rates usually observed in other studied areas. These findings were in accordance with the extremely reduced parasitological prevalence data obatined by the Kato-Katz method and with the historical aspects of schistosomiasis in the area. Infected snails were reported, and autochthonous cases of schistosomiasis have been notified in the area, not for a long time in the past (Sucen 1987, 1989b). The number of serologically positive individuals in the studied population is small, but it represents an expressive number when compared to the number of individuals detected by the fecal examination. Such difference can be associated to several conditions: better sen-

\section{TABLE III}

Number of schoolchildren for each possible combination of results of the serological test (IgM-IFT) carried out on 162 schoolchildren who participated in the project since the 1st survey and submitted blood samples to all of the five surveys

\begin{tabular}{lccccc}
\hline \multirow{2}{*}{$\begin{array}{l}\text { No. of } \\
\text { schoolchildren }\end{array}$} & \multicolumn{5}{c}{ Results of IgM-IFT in each survey } \\
\cline { 2 - 6 } & 2nd sem/92 & 1st sem/93 & 2nd sem/93 & 1st sem/94 & 2nd sem/94 \\
\hline 151 & $\mathrm{~N}$ & $\mathrm{~N}$ & $\mathrm{~N}$ & $\mathrm{~N}$ & $\mathrm{~N}$ \\
6 & $\mathrm{P}$ & $\mathrm{P}$ & $\mathrm{P}$ & $\mathrm{P}$ & $\mathrm{P}$ \\
2 & $\mathrm{~N}$ & $\mathrm{P}$ & $\mathrm{P}$ & $\mathrm{P}$ & $\mathrm{P}$ \\
1 & $\mathrm{~N}$ & $\mathrm{P}$ & $\mathrm{P}$ & $\mathrm{P}$ & $\mathrm{N}$ \\
1 & $\mathrm{P}$ & $\mathrm{N}$ & $\mathrm{N}$ & $\mathrm{N}$ & $\mathrm{N}$ \\
1 & $\mathrm{P}$ & $\mathrm{P}$ & $\mathrm{P}$ & $\mathrm{P}$ & $\mathrm{N}$ \\
\hline
\end{tabular}


sitivity of the serological method, failure of the parasitological method in the cases of low worm burden, cross reactions with other parasites or free cercariae, and persistence of antibodies in individuals with past infection. The data on Table II, showing higher serological rates in the older age groups, can suggest difficulties in detecting S. mansoni eggs in individuals with chronic infection or even persistence of IgM antibodies in individuals after cure. These factors must be studied for better understanding of the real meaning of the serological and parasitological prevalence data obtained in this area.

The IgM-IFT, when applied for a serological follow-up in a school population of the municipality of Itariri, Vale do Ribeira, another schistosomiasis endemic region in the State of São Paulo, showed occurrence of seasonal transmission of schistosomiasis. In that area, higher rates of seroconversion from negative to positive IgM-IFT were observed in post-summer surveys, when compared to the post-winter surveys (Kanamura et al. 1998b). In the school population of Ribeirão Pires, this seasonal transmission pattern was not observed (Table III), suggesting that in this area the risk of exposure to the cercariae is low. Seroconversion was observed only from the 1st to the 2nd survey, probably indicating a sporadic transmission of schistosomiasis; parasitological confirmation was possible only in one of the three cases of seroconversion. In other few cases, the possible occurrence of seroconversion was not possible to be confirmed because of failure in the collection of blood samples or occurrence of fluctuations in the results of the IgM-IFT. In some individuals with low levels of IgM antibodies, close to the cut off value, oscillations in the results of the IgMIFT, altering from negative to positive, and than to negative again, were occasionally observed. The great number of children serologically negative throughout the follow-up, or at least in four surveys, confirms the low level of schistosomiasis transmission in the studied area. The situation must be probably similar in other areas of Great São Paulo. Nevertheless, it is unquestionable the necessity of a schistosomiasis vigilance program in the region, since it is real the presence of the snail host and of infected individuals, continually arriving from other states or endemic areas of São Paulo. Also it is not possible to ignore the notification of few sporadic cases of autochthonous schistosomiasis infection in the area. Thus, the serological method must be more efficient than parasitological method as a diagnostic instrument for the vigilance program in such a low endemic area.

Our results suggest that the IgM-IFT on worm paraffin sections is a practical and useful test for epidemiological purposes, because of its high sen- sitivity for detection of infection in a very precocious phase, and high stability of the antigen at room temperature. It can be useful for differentiating areas with and without active transmission better than parasitological methods. This method can be introduced as a valuable diagnostic tool to select individuals for ulterior confirmation by parasitological methods, and to improve the schistosomiasis control program of the Great São Paulo.

\section{AKNOWLEDGEMENTS}

To the technicians Maria Alice da Silva, Ana Claudia de Araújo and José Arcanjo Filho for excellent help in the laboratory and in the fieldwork.

\section{REFERENCES}

Barreto ML, Smith DH, Sleigh AC 1990. Implications of faecal egg count variation when using the KatoKatz method to assess Schistosoma mansoni infections. Trans R Soc Trop Med Hyg 84: 554-555.

Correa-Oliveira R, Dusse LM, Viana IR et al. 1988. Human antibody response against schistosomal antigens. I. Antibodies from patients with Ancylostoma, Ascaris lumbricoides or Schistosoma mansoni infections react with schistosome antigens. Am J Trop Med Hyg 38: 348-355.

Dean AG, Dean JA, Coulombier D et al. 1995. Epi Info, Version 6: a word processing, database, and statistics program for public health on IBM-compatible microcomputers, Centers for Disease Control and Prevention, Atlanta, GA.

De Vlas SJ, Gryseels B 1992. Underestimation of Schistosoma mansoni prevalences. Parasitol Today 8: 274277.

Dias LCS, Camargo ME, Hoshino-Shimizu S et al. 1971. Inquéritos populacionais de esquistossomose mansoni por técnicas sorológicas de imunofluorescência e de hemaglutinação. Rev Inst Med Trop S Paulo 13: 37-44.

Dias LCS, Kanamura HY, Hoshino-Shimizu S et al. 1992. Field trials for immunodiagnosis with reference to Schistosoma mansoni, p. 39-47. In NR Bergquist, Immunodiagnostic Approches in Schistosomiasis, John Wiley \& Sons, Chichester.

Eltiro F, Ye-ebiyo Y, Taylor MG 1992. Evaluation of an enzyme linked immunosorbent assay (ELISA) using Schistosoma mansoni soluble egg antigen as a diagnostic tool for Schistosoma mansoni infection in Ethiopian schoolchildren. J Trop Med Hyg 95: 52-56.

Emplasa 1994. Empresa Metropolitana de Planejamento da Grande São Paulo SA. Plano Metropolitano da Grande São Paulo 1993 /2010, 256 pp.

Engels D, Sinzinkayo E, Gryseels B 1996. Day-to-day egg count fluctuation in Schistosoma mansoni and its operational implications. Am J Trop Med Hyg 54: 319-324.

Ferreira CS, Carvalho ME 1982. Padronização de uso de papel-filtro como suporte de material para reações sorológicas. Rev Bras Malariol 34: 82-86.

Hoshino-Shimizu S, Camargo MC, Kawada HYK, Silva LC, Dias LCS 1986. Aspectos sorológicos e soroepidemiológico da esquistossomose mansônica, 
p. 67-89. In FA Reis, I Faria, N Katz (eds), Modernos Conhecimentos sobre Esquistossomose Mansônica. Anais da Academia Mineira de Medicina 14 (Suppl).

Idris MA, Ruppel A, Numrich P et al. 1994. Schistosomiasis in the southern region of Oman: vector snail and serological identification of patients in several locations. J Trop Med Hyg 97: 205-210.

Kanamura HY, Silva RM, Rabello ALT, Rocha RS, Katz N 1991. Anticorpos séricos IgA no diagnóstico da fase aguda da esquistossomose mansoni humana. Rev Inst Adolfo Lutz 51: 101-104.

Kanamura HY, Dias LCS, Silva RM et al. 1998a. A comparative epidemiologic study of specific antibodies (IgM and $\operatorname{IgA}$ ) and parasitological findings in an endemic area of low transmission of S. mansoni. Rev Inst Med Trop S Paulo 40: 85-91.

Kanamura HY, Dias LCS, Glasser CM et al. 1998b. Detection of IgM antibodies to Schistosoma mansoni gut-associated antigens for the study of the dynamics of schistosomiasis transmission in a low endemic area. Rev Inst Med Trop S Paulo 40 (in press).

Katz N, Chaves A, Pellegrino J 1972. A simple device for quantitative stool thick-smear technique in schistosomiasis mansoni. Rev Inst Med Trop S Paulo 14: 397-400.

Kawazoe U, Hoshino-Shimizu S, Correa NS et al. 1981. An immunoepidemiological study of schistosomiasis in Paraiba's Valley, São Paulo, Brazil. Rev Inst
Med Trop S Paulo 23: 36-40.

Nash TE 1978. Antibody response to a polysaccharide antigen present in the schistosome gut. I. Sensitivity and specificity. Am J Trop Med Hyg 27: 938-943.

Noya O, Losada S, Noya BA et al 1995. Effect of chemotherapy on immune response to egg antigens of Schistosoma mansoni in chronically infected children from areas of low transmission. Paras Immunol 17: 111-117.

Silva RM, Silva MIPG, Vellosa SAG, Kanamura HY 1992. Pesquisa de anticorpos IgM contra tubo digestivo do verme para o diagnóstico da esquistossomose mansônica. Rev Bras Pat Clin 28: 39-42.

Sucen 1987. Superintendência de Controle de Endemias. Avaliação da Esquistossomose na Região da Grande São Paulo. São Paulo (Relatório).

Sucen 1989a. Superintendência de Controle de Endemias. Programa de Controle da Esquistossomose do Estado de São Paulo, São Paulo [mimeo].

Sucen 1989b. Superintendência de Controle de Endemias. Boletim Trimestral de Atividades Grande São Paulo - $2^{\circ}$ Trimestre de 1989, São Paulo (mimeo).

Valli LCP, Kanamura HY, Silva RM et al. 1997. Efficacy of an enzyme-linked immunosorbent assay in the diagnosis of and serologic distinction between acute and chronic Schistosoma mansoni infection. Am J Trop Med Hyg 57: 358-362. 